\title{
KINETIC AND MECHANISM OF ARSENIC IONS REMOVAL BY ADSORPTION ON LEONARDITE CHAR AS LOW COST ADSORBENT MATERIAL
}

\author{
YUTTASAK CHAMMUI ${ }^{1}$, PONLAYUTH SOOKSAMITI ${ }^{2}$, WIMOL NAKSATA ${ }^{1}$, ORN-ANONG ARQUEROPANYO*1,3 \\ 'Department of Chemistry, Faculty of Science, Chiang Mai University, Chiang Mai, Thailand 50200 \\ ${ }^{2}$ Department of Primary Industry and Mine Office Region 3, Chiang Mai, Thailand 50200 \\ ${ }^{3}$ Materials Science Research Center, Faculty of Science, Chiang Mai University, Chiang Mai 50200, Thailand
}

(Received: September 6, 2013 - Accepted: February 13, 2014)

\begin{abstract}
Adsorption is one of the important techniques in arsenic removal from aqueous solutions. In this study, the As removal efficiency of Leonardite char by a prepared Leonardite carbonized at $450^{\circ} \mathrm{C}$ was investigated as a function of solution $\mathrm{pH}$, contact time, kinetic and $\mathrm{As}(\mathrm{III})$ or $\mathrm{As}(\mathrm{V})$ concentration. The surface complexation modeling was used to describe $\mathrm{As}(\mathrm{III})$ and $\mathrm{As}(\mathrm{V})$ adsorption on the minerals which found in Leonardite char. In the batch experiment, $10.0 \mathrm{mg} / \mathrm{L}$ $\mathrm{As}(\mathrm{III})$ or $\mathrm{As}(\mathrm{V}) \mathrm{pH} 7.0$ and $50 \mathrm{~mL}$ of aqueous solution was as high as $90 \%$ adsorbed. The results showed that Leonardite char could be used as effective adsorbent for the removal of arsenic from aqueous solution. This research supports effort to water with arsenic level lower than $10 \mathrm{mg} / \mathrm{L}$. The maximum adsorption capacity was calculated by fitting the Langmuir and Freunchlich equations to the adsorption isotherms. The Leonardite char will be used as a low-cost adsorbent, for arsenic ions removal in water.
\end{abstract}

Keywords: Leonardite char, Adsorbent, Arsenic, Langmuir, Freundlich, Pseudo-second-order.

\section{INTRODUCTION}

Leonardite is a natural raw material containing a high content of humic matter. It derives from lignite that has undergone oxidation during surface exposure or represents sediments enriched in humic acids that were leached from topsoil ${ }^{1}$. A significant difference between lignite and Leonardite is the oxygen content; Leonardite usually contains about $28-29 \%$, while lignite contains about $19-20 \%{ }^{2}$. In the Northern region of Thailand have a large open pit lignite mine and used for electric generation. Leonardite was found at benches outcrop of the mine which has humic acid content $20-40 \%$ or more and economically used for humic acids extraction. Because of Leonardite have a low heating value and some inorganic minerals which content accelerates erosion of furnace burner. Then, it was dumped as mine waste in the mines. Generally, minerals in Leonardite vary widely; the amount present is the shale group (muscovite, illite), the clay group, the sulfide group, carbonate group and the salt group ${ }^{3}$. Many researchers studied Leonardite or Leonardite char as low cost adsorbents for removal cations in water or gas $^{4-6}$. A low grade Leonardite identifies by the containing of humic acid which is lower than $15 \%$ and high mineral matter. In the mine, a low grade Leonardite was dumped on-site storage in lignite mine and made problem to the surrounding area and have a negative impact on aquatic and terrestrial systems through runoff.

Various techniques have been used for the removal of arsenic (As) from water and wastewater such as classical methods (adsorption, precipitation, ion exchange and reverse osmosis). Of these, adsorption technique is especially in mining area as where arsenic are being released to the environment ${ }^{7}$. Consequently, attempts have been to find a simple and efficient low cost absorbent. The removing of As through chemical sorption process is high effective method but it has high cost to operation ${ }^{8-10}$. Current technologies for the remediation of waters contaminated by heavy metals usually rely either on in situ capping or excavation, removal and disposal of the contaminated material. For removal of arsenic ions in dilute concentration, adsorption is one of suitable methods ${ }^{11}$. Previous studies of As ions adsorption have been focused on clay minerals and iron oxide minerals because of their high affinity for $\mathrm{As}(\mathrm{V})^{12}$. In this study the authors have concentrated on investigating the arsenic adsorption behavior on modified low grade Leonardite which is low cost adsorbent.

\section{EXPERIMENTAL}

Preparation of Leonardite char

Leonardite was obtained from Mae Moh lignite mine Lampang province, Thailand. The sample was air dried, ground and sieved, the fraction of less than 80 mesh was used in this experiment. Char was prepared by carbonization of ground low grade Leonardite in muffle furnace at $450^{\circ} \mathrm{C}$ for 6 hours. After cooling, the char was washed with deionized water 4-5 times and then dried in an electric oven at $105^{\circ} \mathrm{C}$. The sample was kept in desiccators.

\section{Characterization}

The crystals morphologies of Leonardite and char samples were examined by Scanning Electron Microscope (SEM) (LEO 1455 VP, England). The samples were examined mineral crystallography by X-ray diffraction spectrometer (XRD, Bruker D 8-Advance diffractometer) with $\mathrm{Cu} \mathrm{K}_{\alpha}$ radiation in the $2 \theta$ ranging $5^{\circ}-75^{\circ}$. The major chemical compositions of Leonardite char were analyzed by X-ray fluorescence spectrometer (XRF, Magix pro MUA/ USEP T84005, Philips).

\section{Adsorption experiment}

To study the removal of As from aqueous solution, the batch experiments were carried out under static and shaking conditions. Under static condition, a $50 \mathrm{~mL}$ of $10.0 \mathrm{mg} / \mathrm{L}$ As(III or V) solution was taken in $125 \mathrm{~mL}$ erlenmeyer flask containing $0.1 \mathrm{~g}$ of the adsorbent. The mixture was left for a certain time interval and then the aqueous solution was removed to measure As concentration. Under shaking condition, the mixture was shaken for certain time $(10,30,60,180,360,720,1440$ and $2880 \mathrm{~min})$ using a mechanical shaker which controlled speed at $125 \mathrm{rpm}$. After each shaken interval, the aqueous solution was decanted and filtered. Arsenic analysis was carried out using a Hydride Generation Atomic Absorption Spectrometer (HG-AAS, HS 60 Hydride system NOV AA 350, Analytik Jena, Germany).

Effects of $\mathrm{pH}$ on As adsorption

The effects of $\mathrm{pH}$ solution on the $\mathrm{As}(\mathrm{III})$ or $\mathrm{As}(\mathrm{V})$ were investigated by using shaking condition. The solution was adjusted to $\mathrm{pH} 4,7$ and 10 using $0.01 \mathrm{M} \mathrm{HCl}$ and $0.01 \mathrm{M} \mathrm{NaOH}$ solutions with an initial As concentration of 10.0 $\mathrm{mg} / \mathrm{L}$ with shaken at $125 \mathrm{rpm}$. After $3 \mathrm{~h}$, the As concentration was determined by HG-AAS. As(V) was reduced to As(III) with KI and ascorbic acid before hydride generation.

\section{Kinetic modeling}

The transient behavior of the arsenic sorption process was analyzed by using the pseudo-first-order and pseudo-second-order. Application of a single kinetic model to sorption on solid adsorbents may be questionable because of the heterogeneity of adsorbent surfaces and diversity of adsorption phenomena ${ }^{13}$.

The pseudo-first-order (Lagergren first-order) rate equation and its integrated form are as follows:

$$
\frac{\mathrm{dq}}{\mathrm{dt}}=\mathrm{K}_{\text {lads }}\left(\mathrm{q}_{\mathrm{e}}-\mathrm{q}_{\mathrm{t}}\right)
$$




$$
\ln \left(\mathrm{q}_{\mathrm{e}}-\mathrm{q}_{\mathrm{t}}\right)=\ln \mathrm{q}_{\mathrm{e}}-\mathrm{K}_{\text {lads }} \mathrm{t}
$$

where $\mathrm{q}_{\mathrm{e}}$ and $\mathrm{q}_{\mathrm{t}}$ are the amount of adsorbate adsorbed $(\mathrm{mg} / \mathrm{g})$ at equilibrium and at time $\mathrm{t}(\mathrm{min}), \mathrm{K}_{1 \mathrm{ads}}$ is the adsorption rate constant. The values of $\mathrm{K}_{\text {lads }}$ and $q_{e}$ can be calculated from the intercept and slope of the plots of $\ln \left(\mathrm{q}_{\mathrm{e}}-\mathrm{q}_{\mathrm{t}}\right)$ versus t.

The pseudo-second-order equation is also based on the sorption capacity of the solid phase and is expressed as:

$$
\frac{\mathrm{dq}}{\mathrm{dt}}=\mathrm{K}_{2 \mathrm{ads}}\left(\mathrm{q}_{\mathrm{e}}-\mathrm{q}_{\mathrm{t}}\right)^{2}
$$

where $\mathrm{K}_{2 \text { ads }}$ is the rate constant of second-order adsorption. For the same boundary conditions the integrated form becomes:

$$
\frac{\mathrm{t}}{\mathrm{q}_{\mathrm{t}}}=\frac{1}{\mathrm{~K}_{\text {2ads }} \mathrm{q}_{\mathrm{e}}^{2}}+\frac{\mathrm{t}}{\mathrm{q}_{\mathrm{e}}}
$$

Eq. (4) can be rearranged to obtain:

$$
\frac{\mathrm{t}}{\mathrm{q}_{\mathrm{t}}}=\frac{1}{\mathrm{~h}}+\frac{\mathrm{t}}{\mathrm{q}_{\mathrm{e}}}
$$

where $\mathrm{h}$ is the initial rate.

If pseudo-second-order kinetics is applicable, the plot of $t / q$ against $t$ of should give a linear relationship, from which $\mathrm{q}_{\mathrm{e}}, \mathrm{K}_{\text {2ads }}$ and $\mathrm{h}$ can be determined from the slope and intercept of the plot.

The sorption kinetics of $\mathrm{As}(\mathrm{III})$ and $\mathrm{As}(\mathrm{V})$ onto the Leonardite char were performed using $50 \mathrm{~mL}$ of initial As concentrations $10.0 \mathrm{mg} / \mathrm{L}$ in 125 erlenmeyer flask at appropriate $\mathrm{pH}$. The flasks were shaken at different time intervals from 10-2880 min. The Leonardite char was exhibited substantial sorption capacities. The sorption capacities were 1.16 and $1.19 \mathrm{mg} / \mathrm{g}$ for As(III) and $\mathrm{As}(\mathrm{V})$, respectively, in the first $10 \mathrm{~min}$, reaching $1.21 \mathrm{mg} / \mathrm{g}$ for As(III) and $1.24 \mathrm{mg} / \mathrm{g}$ for $\mathrm{As}(\mathrm{V})$ after the equilibrium contact time (180 $\mathrm{min})$.

Adsorption isotherm

The adsorption isotherm was examined using a series of different initial concentrations of $\mathrm{As}(\mathrm{III})$ or $\mathrm{As}(\mathrm{V})(50 \mathrm{~mL}$ ofl $, 2,4,6,8,10,12,14,16,20$, 25 and $30 \mathrm{mg} / \mathrm{L}$ ) solutions at appropriate $\mathrm{pH}$ to which a constant weight of Leonardite char $0.1 \mathrm{~g}$ and applied in $125 \mathrm{ml}$ erlenmeyer flask. The flasks were shaken at $125 \mathrm{rpm}$ with contact time for $180 \mathrm{~min}$ at constant temperature $(25$ $\pm 1^{\circ} \mathrm{C}$ ). The isotherm data were fitted with different models by non-linear regression.

\section{RESULTS AND DISCUSSION}

Characterization of Leonardite char by SEM, XRD and XRF

SEM photographs of Leonardite and Leonardite char were analyzed. The mineral phases before and after char were also manifested by SEM (Figure 1). Leonardite char showed a micro-sized of the mineral phases transform. It can be noted that the minerals were transformed to char at $450^{\circ} \mathrm{C}$ and 6 hours changes in structural characteristics could be observed by XRD.
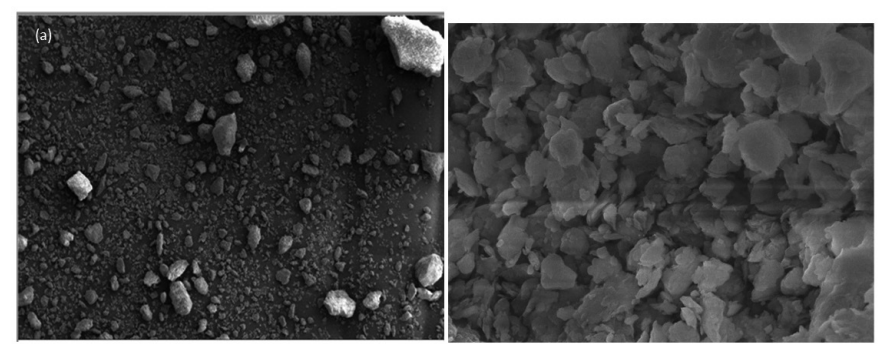

Figure 1: SEM images of Leonardite (a) 200X and Leonardite char (b) $500 X$.

The compositions of the minerals matter of the Leonardite and char were determined by X-ray diffraction spectrometer. There is apparent difference between Leonardite and char (Table 1). It is clear that at the char temperature, transformation of clay minerals, sulfide minerals and alkali minerals was occurred. The XRD pattern of Leonardite indicated clay mineral (montmorillonite), gypsum, pyrite and quartz. The dominated phases in char are as follows: gypsum transforms to anhydrite, pyrite transforms to hematite, quartz, while mixed clay-layers of muscovite. The major and minor metal oxides constituents of the materials analyzed by using XRF are present in Table 2 .

Table 1. Mineralogical compositions of Leonardite and Leonardite char by X-ray diffraction

\begin{tabular}{|c|c|c|}
\hline Compounds & Leonardite & Leonardite Char \\
\hline 1 & $\begin{array}{c}\text { Montmorillonite } \\
\left(\mathrm{Si}_{8} \mathrm{Al}_{4} \mathrm{O}_{20}(\mathrm{OH})_{4}\right)\end{array}$ & $\begin{array}{c}\text { Muscovite } \\
\left(\mathrm{KAl}_{2}\left(\mathrm{AlSi}_{3} \mathrm{O}_{10}\right)(\mathrm{OH})_{2}\right)\end{array}$ \\
\hline 2 & Quartz $\left(\mathrm{SiO}_{2}\right)$ & Quartz $\left(\mathrm{SiO}_{2}\right)$ \\
\hline 3 & $\begin{array}{c}\text { Gypsum } \\
\left(\mathrm{CaSO}_{4} \cdot 2 \mathrm{H}_{2} \mathrm{O}\right)\end{array}$ & Anhydrite $\left(\mathrm{CaSO}_{4}\right)$ \\
\hline 4 & Pyrite $\left(\mathrm{FeS}_{2}\right)$ & Hematite $\left(\mathrm{Fe}_{2} \mathrm{O}_{3}\right)$ \\
\hline
\end{tabular}

Table 2. Chemical compositions of Leonardite and Leonardite char.

\begin{tabular}{|c|c|c|}
\hline Compounds (wt\%) & Leonardite & Leonardite Char \\
\hline $\mathrm{Al}_{2} \mathrm{O}_{3}$ & 14.17 & 26.08 \\
\hline $\mathrm{Fe}_{2} \mathrm{O}_{3}$ & 7.26 & 7.34 \\
\hline $\mathrm{MgO}$ & 1.08 & 1.08 \\
\hline $\mathrm{SiO}_{2}$ & 30.32 & 51.80 \\
\hline $\mathrm{CaO}$ & 1.53 & 5.64 \\
\hline $\mathrm{K}_{2} \mathrm{O}$ & 1.41 & 2.13 \\
\hline $\mathrm{TiO}_{2}$ & 0.44 & 0.48 \\
\hline $\mathrm{SO}_{3}$ & 12.11 & 3.44 \\
\hline $\begin{array}{c}\text { Organic matter and } \\
\text { moisture }\end{array}$ & 31.68 & - \\
\hline
\end{tabular}

Effect of contact time

Figure 2 shows the percent removal of $\mathrm{As}(\mathrm{III})$ and $\mathrm{As}(\mathrm{V})$ with initial concentration $10.0 \mathrm{mg} / \mathrm{L}$ at $\mathrm{pH} 7.0$ on $0.1 \mathrm{~g}$ of Leonardite char as a function of time under shaken and static conditions. In the shaken condition that, \% removal of $\mathrm{As}(\mathrm{III})$ and $\mathrm{As}(\mathrm{V})$ increased gradually with time until attained equilibrium in $180 \mathrm{~min}$. The adsorption rate was rapid and high for both As(III) and $\mathrm{As}(\mathrm{V})$ because the solid adsorbent could move around in the solutions. While static conditions the adsorption of arsenic onto solid adsorbent was very slow process and low amount of As was adsorbed. The maximum removal of $\mathrm{As}(\mathrm{III})$ and $\mathrm{As}(\mathrm{V})$ from the solution was found to be $92.0 \%$ and $95.5 \%$, respectively.

Effect of $\mathrm{pH}$

$\mathrm{As}(\mathrm{III})$ and $\mathrm{As}(\mathrm{V})$ in aqueous acid solution most treatment process are effective for removing $\mathrm{As}(\mathrm{V})$ by not $\mathrm{As}(\mathrm{III})$ because As(III) is typically noncharged in acid medium. A significant change to increase the adsorption of $\mathrm{As}(\mathrm{III})$ has been found at $\mathrm{pH} 4$ to 10 . With the acidic condition, the adsorbent surfaces are highly protonated. In this acidic condition As(III) is in neutral form $\left(\mathrm{H}_{3} \mathrm{AsO}_{3}\right)$ and not in situation to be adsorbed on the adsorbent surface. With the increase in the $\mathrm{pH}$ of system, the degree protonation of surface reduces and favoring the interaction of $\mathrm{H}_{3} \mathrm{AsO}_{3}$. This effect in an increase in the percent of removal of As(III). However, no significant change on adsorption of As(V) was observed at $\mathrm{pH}$ range $4-10$ (Figure 3 ). According to the arsenic species stability diagram, $\mathrm{As}(\mathrm{V})$ the stable species are anionic: $\mathrm{H}_{2} \mathrm{AsO}_{4}^{-}(\mathrm{pH} 3-6)$ and $\mathrm{HAsO}_{4}^{2-}(\mathrm{pH} 7-11)^{14}$. Since more than $90 \%$ of arsenic could be adsorbed at $\mathrm{pH} 7$ to 10 for $\mathrm{As}(\mathrm{III})$, and at $\mathrm{pH} 4$ to $10 \mathrm{for} \mathrm{As}(\mathrm{V})$, therefore, investigation of adsorption kinetics and isotherms was carried out at $\mathrm{pH} 7$. 

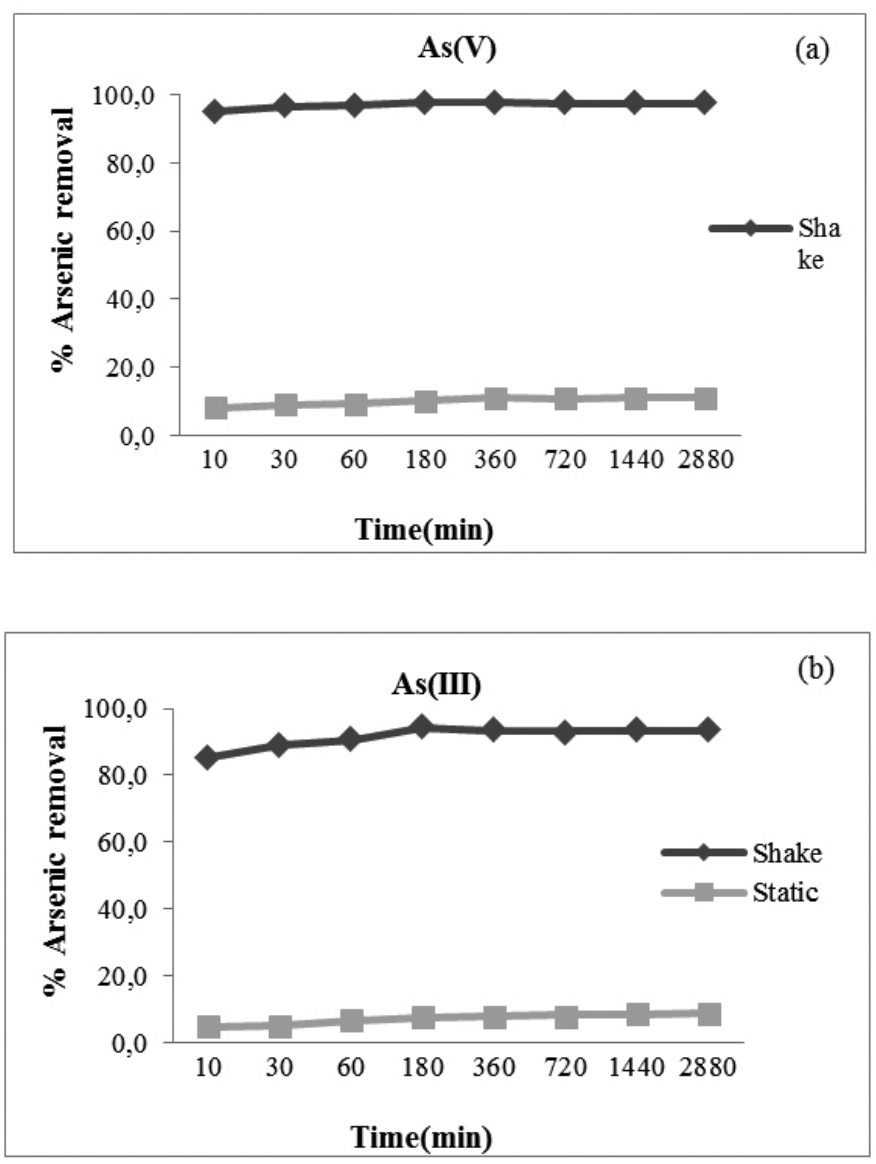

Figure 2: Percent removal of $\mathrm{As}(\mathrm{V})$ (a) and $\mathrm{As}(\mathrm{III})$ (b) with time

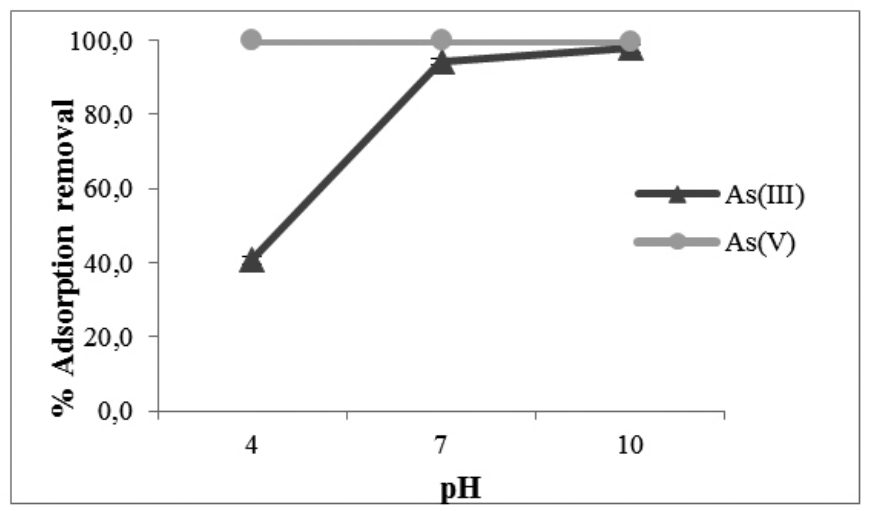

Figure 3: Effect of $\mathrm{pH}$ of solution on removal of $\mathrm{As}(\mathrm{III})$ and $\mathrm{As}(\mathrm{V})$ by adsorption on Leonardite char.

\section{Adsorption kinetics}

Pseudo-first-order model did not fit with the experimental data well. The values of $\mathrm{R}^{2}$ were between 0.41 and 0.42 . Pseudo-second-order model was found to fit with the data very well. The values of $q_{e}, K_{2}$ and $h$ for As(III) were $1.22 \mathrm{mg} / \mathrm{g}, 1.30 \mathrm{mg} / \mathrm{g} \cdot \mathrm{min}$ and $1.94 \mathrm{mg} / \mathrm{g} . \mathrm{min}$, respectively and for As(V) were $1.24 \mathrm{mg} / \mathrm{g}, 2.02 \mathrm{mg} / \mathrm{g} \cdot \mathrm{min}$ and $3.11 \mathrm{mg} / \mathrm{g} . \mathrm{min}$, respectively. The corresponding linear regression coefficient $\mathrm{R}^{2}$ values are 1.0 for both $\mathrm{As}(\mathrm{III})$ and $\mathrm{As}(\mathrm{V})$ (Figure 4).
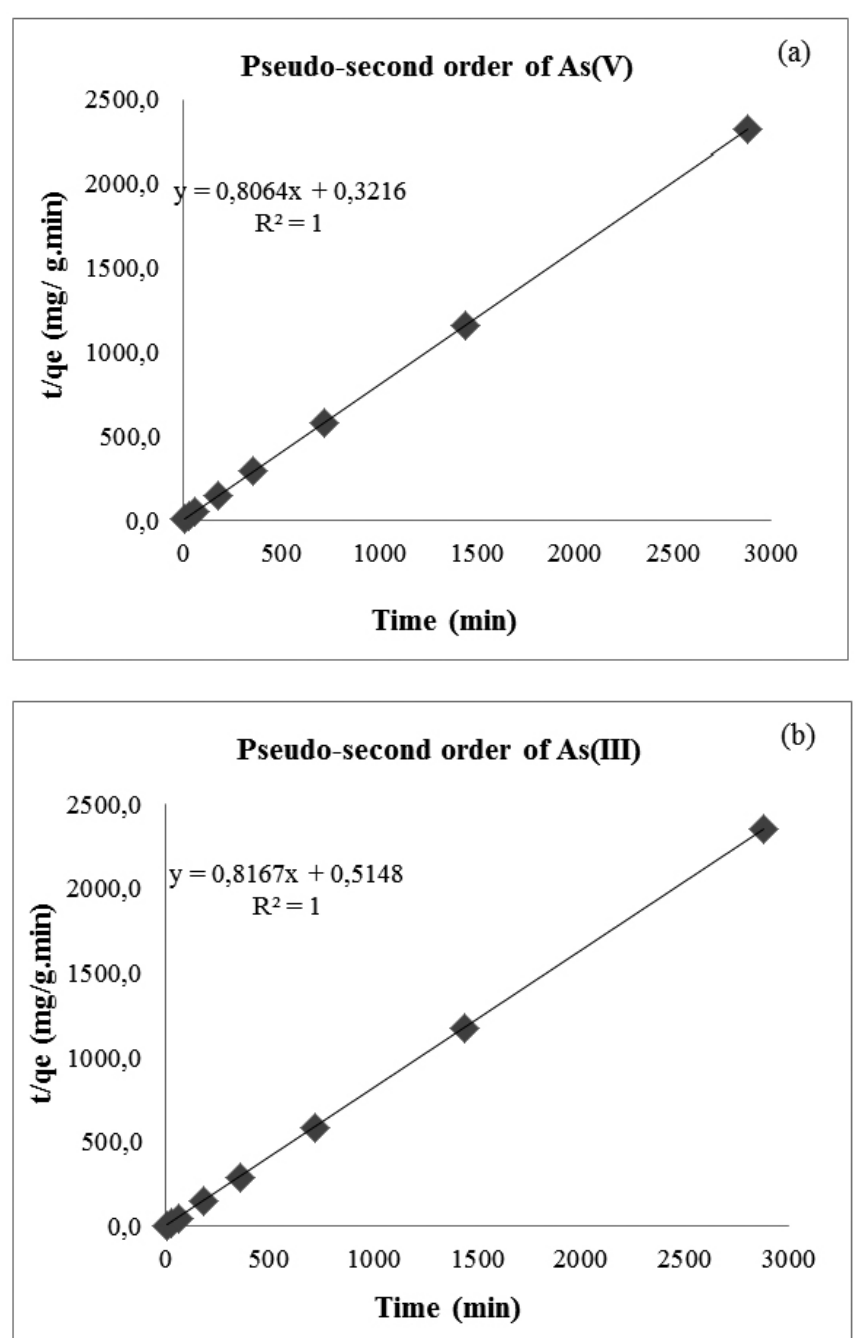

Figure 4: Kinetic model parameters and correlation coefficients for $\mathrm{As}(\mathrm{V})$ (a) and $\mathrm{As}(\mathrm{III})$ (b) sorption.

Adsorption isotherms

To determine the adsorption capacities of Leonardite char for removal arsenic from water, Langmuir and Freundlich adsorption isotherms were used. The constant values of Langmuir and Freundlich isotherms are given in Table 3. The adsorption of $\mathrm{As}(\mathrm{III})$ or $\mathrm{As}(\mathrm{V})$ were fitted with Langmuir and Freundlich isotherms. The maximum adsorption capacity $\left(\mathrm{q}_{\mathrm{m}}\right)$ values of $\mathrm{As}(\mathrm{III})$ was 4.5 $\mathrm{mg} / \mathrm{g}$ and $8.3 \mathrm{mg} / \mathrm{g}$ for $\mathrm{As}(\mathrm{V})$ at $\mathrm{pH}$ 7.0. From Freundlich equation, $n$ value for $\mathrm{As}(\mathrm{III})$ and $\mathrm{As}(\mathrm{V})$ were 2.1 and 4.9, respectively. The linear plots and high $\mathrm{R}^{2}$ values indicated that both Langmuir and Freudlich isotherms could be used to fit the data and

Table 3. Adsorption isotherms constant for $\mathrm{As}(\mathrm{III})$ and $\mathrm{As}(\mathrm{V})$ removal by Leonardite char

\begin{tabular}{|c|c|c|c|}
\hline \multirow{2}{*}{ Model equation } & \multirow{2}{*}{ Parameter } & \multicolumn{2}{|c|}{ Leonardite char } \\
\cline { 3 - 4 } & & As(III) & As(V) \\
\hline \multirow{3}{*}{ Langmuir } & $\mathrm{q}_{\mathrm{m}}(\mathrm{mg} / \mathrm{g})$ & 4.5 & 8.3 \\
& $\mathrm{~b}(\mathrm{~L} / \mathrm{mg})$ & 0.27 & 2.5 \\
& $\mathrm{R}^{2}$ & 0.981 & 0.996 \\
\hline \multirow{3}{*}{ Freundlich } & $\mathrm{K}_{\mathrm{f}}$ & 1.1 & 5.2 \\
& $n$ & 2.1 & 4.9 \\
& $\mathrm{R}^{2}$ & 0.996 & 0.990 \\
\hline
\end{tabular}

estimate model parameters. However, the Freundlich model is better fitted with the experimental data for adsorption of As(III) rather than the Langmuir 
model, whereas, on the other hand, the experimental data for $\mathrm{As}(\mathrm{V})$ adsorption gave a better fit with the Langmuir model. In addition, all Langmuir and Freundlich parameters of $\mathrm{As}(\mathrm{V})$ adsorption were higher than that of As(III) adsorption indicating the stronger interaction with the surface of the Leonardite char.

Arsenic removal mechanisms

From the XRD result, it was shown that Leonardite char mainly consists of clay minerals, ferric oxide (hematite) and quartz. Quartz $\left(\mathrm{SiO}_{2}\right)$ has a siloxane group (-SiOSi-) which can interact with water forming $-\mathrm{Si}_{-} \mathrm{OH}^{15}$. The adsorption of arsenate and arsenite could be on quartz surface with similar in clay surface as defined surface reaction as recommended by Manning et al. ${ }^{12}$. Corresponding with Mohapatra et al. ${ }^{16}$, it was found that kaolinite is the best $\mathrm{As}(\mathrm{V})$ adsorbent and montmorillonite has strong retention capacity. The electrokinetic behavior of kaolinite and montmorillonite was modified in the presence of $\mathrm{As}(\mathrm{V})$, indicating that adsorption involves inner sphere surface complexation and strong specific ion adsorption.

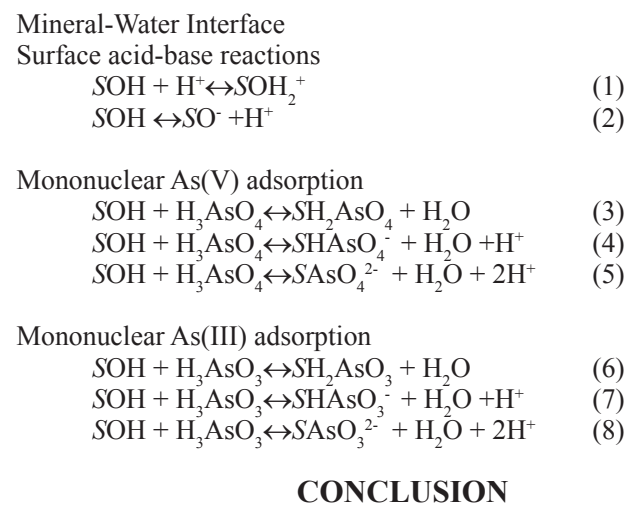

Leonardite char produced from carbonization Leonardite at $450^{\circ} \mathrm{C}$ for 6 $\mathrm{h}$ was used for arsenic removal from water. In the batch experiment, it was shown that the char had efficient to separate both As(III) and As(V) species from water. About $90 \%$ of $\mathrm{As}(\mathrm{III})$ or $\mathrm{As}(\mathrm{V})$ was removed from $50.0 \mathrm{~mL}$ of 10.0 $\mathrm{mg} / \mathrm{L}$ solution( $\mathrm{pH} 7.0$ ) when $0.10 \mathrm{~g}$ of the adsorbent was used with the contact time of $180 \mathrm{~min}$. Adsorption of both As (III) and As (V) corresponded to the pseudosecond order model. The adsorption isotherm followed both Langmuir and Freundlich isotherms. The results obtained in this study will be useful for its further extension to scale column study.

\section{ACKNOWLEDGMENT}

The authors would like to give special thanks to Department of Chemistry, Faculty of Science, Chiang Mai University and Department of Primary Industry and Mine Office Region 3, Chiang Mai for instruments support along this study. This work was also supported by the Higher Education Research Promotion and National Research University Project of Thailand, Office of the Higher Education Commission. The first author would also like to thanks the Center of Excellent for Innovation in Chemistry (PERCH-CIC) and Pibulsongkram Rajabhat University for the graduate scholarships awarded which relieved the author's financial burden and made it possible to complete this research.

\section{REFERENCES}

1.- P.G. Freeman, The Use of Lignite Products as Plant Growth Stimulants Technology and Use of Lignite, IC Bureau of Mines Information Circular, 1969 , pp. 8471; 150153; 160;162; 164.

2.- Humalite, Alberta'S Form of Leonardite, Retread Resources Ltd., Available: http://retreadresources.com/ResourceHumalite.html

3.- G. Ozbayoglu, M.E. Ozbayoglu, Fuel, 85, 545, (2006).

4.- D.E. Schroeder, The Production of Activated Carbon from Leonardite, University of North Dakota, 1969. Length, 162 pages.

5.- B.C. Young, E.S. Olson, C.L. Knudson and R.C. Timpe, Activated carbons from north Dakota lignite and Leonardite, Timpe University of North Dakota Energy, pp. 280-284. Available: http://web.anl.gov/PCS/acsfuel/ preprint\%20archive/Files/40 2 ANAHEIM 04-95 0280.pdf

6.- C.L. Knudson, Leonardite Char Adsorbents, U.S. Patent 5, 254, 521, (1993).

7.- V. Overfort, Environ. Geochem. Health. 14(3), 87, (1992).

8.- M. Borho, P. Wilderer, Water Sci. Technol. 34, 25, (1996).

9.- X. Meng, S. Bang, G.P. Korfiatis, Water Res. 34, 1255, (2000).

10. -K.S. Subramanian, T. Viraragavan, T. Phommavong, S. Tanjore, Water Qual. Res. J. Cannada, 32(3), 551, (1997).

11. -N. Zahra, J. Chem. Soc. Pak. 32(2), 259, (2010).

12. -B.A. Manning, S. Goldberg, Environ. Sci. Technol. 31, 2005, (1997).

13. - Y. Salameh, N. Al-Lagtah, M.N.M Ahmad, S.J. Allen, G.M. Walker, Chem. Eng. J. 160, 440, (2010).

14. -E. Lombi, W.W. Wenzel, R.S. Sletten, J. Plant. Nutr. Soil. Sci. 162, 451, (1999).

15. -X. Fan, D.J. Parker, M.D. Smith, Water Res. 37, 4929, (2003).

16. -D. Mohapatra, D. Mishra, G.R. Chaudhury, R.P. Das, Korean J. Chem. Eng. 24(3), 426, (2012). 